\title{
The effects of sugar-beet fibre and wheat bran on iron and zinc absorption in rats
}

\author{
BY SUSAN J. FAIRWEATHER-TAIT AND A. J. A. WRIGHT \\ AFRC Institute of Food Research, Colney Lane, Norwich NR4 $7 U A$
}

(Received 8 March 1990 - Accepted 8 May 1990)

\begin{abstract}
The addition of $1 \mathrm{~g}$ sugar-beet fibre (Beta Fibre) to $3 \mathrm{~g}$ semi-synthetic diet resulted in a $54 \%$ increase in iron and a $39 \%$ increase in zinc absorption in rats. The same amount of non-starch polysaccharides fed as wheat bran (1.9 g) had no effect on Fe absorption but reduced $\mathrm{Zn}$ absorption by $9 \%$. The inhibitory effect of wheat bran is probably due to its high phytate content, but there is, as yet, no explanation for the enhancement of $\mathrm{Fe}$ and $\mathrm{Zn}$ absorption caused by Beta Fibre. If the effect also occurs in man, it will have important implications for high-fibre diets and mineral nutrition.
\end{abstract}

Dietary fibre: Iron absorption: Zinc absorption: Rat

Public awareness of the recommendations to increase their uptake of complex carbohydrates ('dietary fibre') has led to an increasing demand by consumers for palatable high-fibre foods. Food manufacturers have responded by producing a wide range of products which contain dietary components rich in fibre, such as wheat bran, pea testa (Fairweather-Tait \& Wright, 1985) and, more recently, the fibrous extract of sugar beet, Beta Fibre (British Sugar plc, Peterborough).

Under certain conditions, some foods high in complex carbohydrates may reduce the bioavailability of essential minerals by impairing intestinal absorption. Wheat bran is a good example of such a foodstuff, where the active mineral-binding component is phytate. In groups of the population considered to be at risk with regard to mineral nutrition, such as pregnant women and the elderly, alternative sources of fibre that retain the beneficial effects (notably faecal bulking and reduced intestinal transit time) without the adverse effects on mineral absorption, would clearly offer an advantage. The present study was designed to compare the effects of wheat bran and Beta Fibre on iron and zinc absorption in rats.

\section{MATERIALS AND METHODS \\ Animals and diets}

One hundred and forty male Wistar rats weighing 140-160 g were caged individually in stainless-steel and plastic cages with wire-gridded bottoms, and fed on a semi-synthetic diet (Table 1) for 2 weeks. During the second week they were allocated randomly to seven groups of twenty animals and trained to meal-feed.

\section{Absorption study}

After an overnight fast, each rat was given a test meal of $3 \mathrm{~g}$ semi-synthetic diet (in which the Solka Floc was replaced by equal amounts of starch and sucrose) together with $1 \mathrm{~g}$ Beta Fibre or $1.9 \mathrm{~g}$ wheat bran as outlined in Table 2. The relative proportions of Beta Fibre and 
Table 1. Composition of semi-synthetic diet $(\mathrm{g} / \mathrm{kg})$

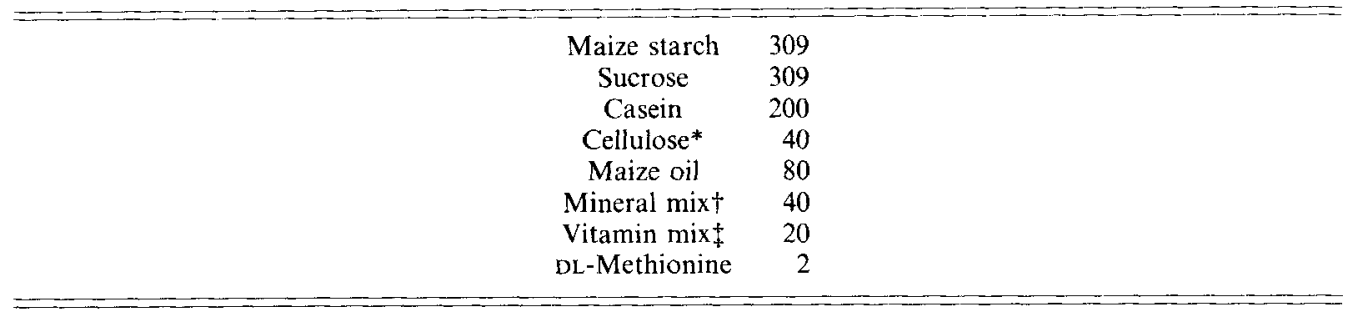

* Solka Floc; Johnson, Jurgensen \& Wettre Ltd, London.

$\dagger$ Provided (g/kg diet): $\mathrm{CaHPO}_{4} 13 \cdot 0, \mathrm{Na}_{2} \mathrm{HPO}_{4} 7 \cdot 4, \mathrm{CaCO}_{3} 8 \cdot 2, \mathrm{KCl} 7 \cdot 03, \mathrm{MgSO}_{4} . \mathrm{H}_{2} \mathrm{O} 4.0, \mathrm{ZnCO}_{3} 0.025$, $\mathrm{FeSO}_{4} .7 \mathrm{H}_{2} \mathrm{O} 0 \cdot 144, \mathrm{CuSO}_{4} .5 \mathrm{H}_{2} \mathrm{O} 0 \cdot 023, \mathrm{KIO}_{3} 0 \cdot 001, \mathrm{MnSO}_{4} . \mathrm{H}_{2} \mathrm{O} 0 \cdot 18$.

$\$$ Provided (mg/kg diet): nicotinic acid 60, cyanocobalamin in mannitol (Glaxo) 50, calcium D-pantothenate 40 , thiamin hydrochloride 10 , riboflavin 10 , pyridoxine 10 , pteroylmonoglutamic acid 10 , D-biotin 1 , vitamin $\mathrm{K}_{1}$ 2, Rovimix E-50 (containing $75 \mathrm{mg}$ as DL- $\alpha$-tocopheryl acetate; Roche) 150, Rovimix A-500 25 (containing $3.75 \mathrm{mg}$ as retinol; Roche), Rovimix $\mathrm{D}_{3}-50015$ (containing $188 \mu \mathrm{g}$ as cholecalciferol; Roche), choline bitartrate 1800 , starch (bulking agent) 17817.

Table 2. Composition of sugar-beet fibre (Beta Fibre; British Sugar plc) and wheat-brancontaining test meals fed to rats

\begin{tabular}{|c|c|c|c|c|}
\hline $\begin{array}{l}\text { Group } \\
\text { no. }\end{array}$ & Meal & $\begin{array}{c}\text { Mineral } \\
\text { level } \\
(\mu \mathrm{g})\end{array}$ & $\begin{array}{c}\text { Total level } \\
\text { of mineral } \\
\text { in meal }(\mu \mathrm{g})\end{array}$ & $\begin{array}{l}\text { Total non-starch } \\
\text { polysaccharides } \\
\text { in meal }(\mathrm{g})\end{array}$ \\
\hline \multicolumn{5}{|l|}{$\mathrm{Fe}$} \\
\hline \multirow[t]{2}{*}{1} & $3 \mathrm{~g} \mathrm{~s} / \mathrm{s}$ diet* & 111 & 437 & 0.67 \\
\hline & $1 \mathrm{~g}$ Beta Fibre & 326 & & \\
\hline \multirow[t]{2}{*}{2} & $3 \mathrm{~g} \mathrm{~s} / \mathrm{s}$ diet* & 111 & 373 & 0.67 \\
\hline & $1.9 \mathrm{~g}$ wheat bran & 262 & & \\
\hline \multirow[t]{2}{*}{3} & $3 \mathrm{~g} \mathrm{~s} / \mathrm{s}$ diet* & I11 & 405 & Negligible \\
\hline & $1460 \mu \mathrm{g} \mathrm{FeSO}_{4} .7 \mathrm{H}_{2} \mathrm{O}$ & 294 & & \\
\hline \multicolumn{5}{|c|}{ 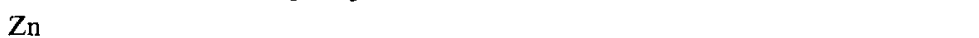 } \\
\hline \multirow[t]{2}{*}{4} & $3 \mathrm{~g} \mathrm{~s} / \mathrm{s}$ diet* & 63 & 78 & 0.67 \\
\hline & $1 \mathrm{~g}$ Beta Fibre & 15 & & \\
\hline \multirow[t]{2}{*}{5} & $3 \mathrm{~g} \mathrm{~s} / \mathrm{s} \mathrm{diet*}$ & 63 & 78 & Negligible \\
\hline & $29 \mu \mathrm{g} \mathrm{ZnCO}_{3}$ & 15 & & \\
\hline \multirow[t]{2}{*}{6} & $3 \mathrm{~g} \mathrm{~s} / \mathrm{s} \mathrm{diet} *^{3}$ & 63 & 225 & 0.67 \\
\hline & $1.9 \mathrm{~g}$ wheat bran & 162 & & \\
\hline \multirow[t]{2}{*}{7} & $3 \mathrm{~g} \mathrm{~s} / \mathrm{s}$ diet $^{*}$ & 63 & 225 & Negligible \\
\hline & $312 \mu \mathrm{g} \mathrm{ZnCO}_{3}$ & 162 & & \\
\hline
\end{tabular}

s/s, Semi-synthetic diet.

* Cellulose replaced by equal amounts of starch and sucrose.

wheat bran were chosen such that the total non-starch polysaccharide content of the test meals, $0.7 \mathrm{~g}$, was identical. Control groups were given a diet with either added $\mathrm{Fe}$ (as ferrous sulphate) or zinc (as zinc carbonate) but no added fibre. In the case of Fe, the total amount in the Beta Fibre meal $(437 \mu \mathrm{g})$ was not dissimilar to that in the wheat bran meal $(373 \mu \mathrm{g})$, and only one control group was used, at a level of $405 \mu \mathrm{g}$ Fe (Table 2). For $\mathrm{Zn}$, the differences between the two fibre meals were quite different, therefore two controls were used, one for Beta Fibre ( $78 \mu \mathrm{g} \mathrm{Zn}$ ) and one for wheat bran (225 $\mathrm{g} \mathrm{Zn}$ ) (Table 2).

Meals were extrinsically labelled with $18 \mathrm{kBq}{ }^{59} \mathrm{Fe}$ (ferric chloride in $0.1 \mathrm{M}$-hydrochloric acid; Amersham International plc, Amersham, Bucks.) or $37 \mathrm{kBq}{ }^{65} \mathrm{Zn}$ (zinc chloride in 
$0 \cdot 1 \mathrm{M}-\mathrm{HCl}$, Amersham International plc). Mineral absorption was measured using a smallanimal whole-body gamma counter (NE8112; NE Technology, Beenham, Berks), as described previously (Fairweather-Tait \& Wright, 1984). All animals were counted immediately after consuming the meal, fasted for $5 \mathrm{~h}$, and then given the semi-synthetic diet ad lib until the end of the study.

Groups given ${ }^{59} \mathrm{Fe}$-labelled meals were counted $7 \mathrm{~d}$ later and percentage retention (apparent absorption) calculated, making due allowance for radioactive decay and counting efficiency. This value was taken to represent true absorption of the mineral from the meal, since losses of absorbed ${ }^{59} \mathrm{Fe}$ during the course of the study were very small. In the case of ${ }^{65} \mathrm{Zn}$, where losses were greater and, hence, apparent absorption significantly less than true absorption, the animals were counted six times in the period 5-14 d after the test meal (during which time the daily percentage loss of $\mathrm{Zn}$ remained constant). Regression analysis was performed on the logarithmically transformed data and from this true absorption was estimated.

\section{Fibre sources}

Wheat bran was ground in a stainless-steel coffee grinder to pass through a $500 \mu \mathrm{m}$ sieve.

The sugar-beet fibre had a particle size of $<0.6 \mathrm{~mm}$, and is marketed under the name of Beta Fibre by British Sugar plc, Peterborough, as a fibre supplement for human consumption.

\section{Analytical methods}

The fibre samples were analysed in duplicate for non-starch polysaccharides by the Englyst method (Englyst et al. 1982) and phytate by anion exchange (Harland \& Oberleas, 1986).

$\mathrm{Fe}$ and $\mathrm{Zn}$ determinations were carried out on dry ashed material (heated to $480^{\circ}$ for $48 \mathrm{~h}$ in silica crucibles) in triplicate. The ash was dissolved in hot concentrated $\mathrm{HCl}$ (Analar) and the mineral concentration of the resultant solution measured by flame atomic absorption spectroscopy (PU9000; Pye Unicam, Cambridge). Analytical accuracy was confirmed using NBS Standard Reference Materials (Office of Standard Reference Materials, Washington DC, USA).

\section{Statistical analysis}

Results of percentage absorption from each test meal for each mineral were compared with the relevant control group using Student's $t$ test (Bailey, 1964).

\section{RESULTS}

The non-starch polysaccharides, phytate, $\mathrm{Fc}$ and $\mathrm{Zn}$ concentrations of Beta Fibre and wheat bran are given in Table 3. Beta Fibre contains nearly twice as much non-starch polysaccharides as wheat bran, and is notably richer in uronic acid and cellulose. The phytate content of Beta Fibre is very low, about seventy times less than that of wheat bran. There is more Fe but less $\mathrm{Zn}$ in Beta Fibre than in wheat bran.

There were no significant differences in the mean body-weight between groups of rats the day before the test meal. The overall mean was $244 \mathrm{~g}$.

Mean absorption from the test meals is given in Table 4 . Wheat bran had no effect on Fe absorption, but it significantly reduced $\mathrm{Zn}$ absorption $(P<0.05)$. Conversely, Beta Fibre increased both $\mathrm{Fe}$ and $\mathrm{Zn}$ absorption from the mixture of endogenous and added mineral. The effect in both cases was highly significant $(P<0 \cdot 001)$. 
Table 3. Non-starch polysaccharides $(\mathrm{mg} / \mathrm{g})$, phytate $(\mathrm{mg} / \mathrm{g})$ and iron and zinc $(\mu \mathrm{g} / \mathrm{g})$ concentrations of Beta Fibre (British Sugar plc) and wheat bran

\begin{tabular}{|c|c|c|}
\hline & Beta Fibre & Wheat bran \\
\hline Rhamnose & 24 & 19 \\
\hline Arabinose & 185 & 79 \\
\hline Xylose & 11 & 157 \\
\hline Mannose & $\operatorname{Tr}$ & $\operatorname{Tr}$ \\
\hline Galactose & 45 & 9 \\
\hline Glucose & 22 & 28 \\
\hline Uronic acid & 220 & 5 \\
\hline $\begin{array}{l}\text { Total non-cellulosic } \\
\text { polysaccharides }\end{array}$ & 507 & 297 \\
\hline Cellulose & 157 & 55 \\
\hline $\begin{array}{l}\text { Total non-starch } \\
\text { polysaccharides }(\mathrm{mg} / \mathrm{g})\end{array}$ & 664 & 352 \\
\hline Phytate* (mg/g) & 0.5 & $36 \cdot 6$ \\
\hline Iron $(\mu \mathrm{g} / \mathrm{g})$ & 326 & 138 \\
\hline Zinc $(\mu \mathrm{g} / \mathrm{g})$ & 15 & 85 \\
\hline
\end{tabular}

* Detection limit about $0 \cdot 1 \mathrm{mg} / \mathrm{g}$.

Table 4. Iron and zinc absorption from a semi-synthetic diet $(3 \mathrm{~g})$ with and without added Beta Fibre (British Sugar plc) $(1 \mathrm{~g})$ or wheat bran $(1.9 \mathrm{~g}) \dagger$

(Mean values with their standard errors for twenty rats)

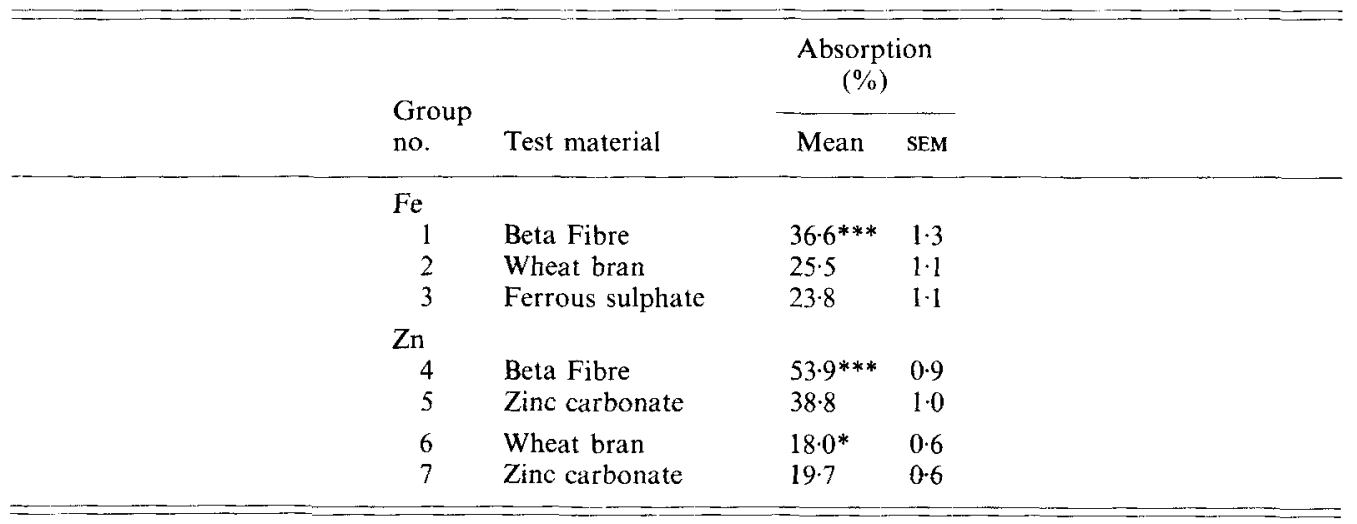

Mean value for test material was significantly different from relevant reference salt: ${ }^{*} P<0.05, * * * P<0.001$.

$\uparrow$ For details of test meals, see Table 2.

\section{DISCUSSION}

The results of the present study demonstrate that wheat bran and sugar-beet fibre have very different modifying influences on mineral absorption. Undoubtedly this is related to their different chemical composition, as has been shown in other studies. For example, Cook et al. (1983) found that wheat bran had a greater inhibitory effect on Fe absorption than pectin or cellulose. Although there is still some controversy regarding the mechanism whereby certain foods rich in complex carbohydrates impair mineral absorption, a great deal of evidence points towards phytate as the active constituent, particularly in the case of $\mathrm{Zn}$. Sandström et al. (1987) found a negative correlation between phytic acid content and $\mathrm{Zn}$ absorption by humans from cereals, and when the phytic acid levels were reduced by 
cooking, $\mathrm{Zn}$ absorption increased. The fact that Beta Fibre contains virtually no phytic acid, whereas wheat bran is quite a rich source of this anti-nutrient, may be the primary explanation for the differences observed between the two with respect to $\mathrm{Fe}$ and $\mathrm{Zn}$ absorption.

The levels of $\mathrm{Fe}, \mathrm{Zn}$ and non-starch polysaccharides in the test meals were calculated to represent a scaled-down version of human diets. Assuming a daily intake by humans of $12 \mathrm{mg} \mathrm{Fe}, 12 \mathrm{mg} \mathrm{Zn}$ and $25 \mathrm{~g}$ non-starch polysaccharides (NSP), the NSP:mineral ratio is about 2000. In rats, the daily intake from the semi-synthetic diet was $1 \mathrm{mg} \mathrm{Fe}$ and $0.5 \mathrm{mg} \mathrm{Zn}$ (for the purposes of the calculation, a mean of $0.75 \mathrm{mg}$ will be used). In order to get an NSP:mineral ratio of 2000 , an intake of $2.5 \mathrm{~g}$ of NSP is required. The test meals contained $0.7 \mathrm{~g} \mathrm{NSP}$, approximately $30 \%$ of the daily amount calculated to provide an NSP: mineral ratio of 2000 . The meals also contained $37-44 \%$ of the daily $\mathrm{Fe}$ intake and $16-45 \%$ of daily $\mathrm{Zn}$ intake. Thus, as far as it was possible, the amounts of wheat bran and Beta Fibre used in the test meals were related to the situation found in human dietaries.

It has been established that non-haem-Fe forms a common pool in the gut with which added Fe isotopes fully exchange (Bjorn-Rasmussen et al. 1973). Thus ${ }^{59} \mathrm{Fe}$ can be used to extrinsically label and measure $\mathrm{Fe}$ absorption from a semi-synthetic diet. In the meals containing Beta Fibre and wheat bran, the semi-synthetic diet contributed 34 and $42 \%$ of the total $\mathrm{Fe}$ respectively. About three-quarters of the $\mathrm{Fe}$ in the semi-synthetic diet was added $\mathrm{FeSO}_{4}$, the other $25 \%$ originating from the dietary ingredients. Wheat bran, unlike Beta Fibre, had no effect on Fe absorption by rats, which is not surprising bearing in mind that $\mathrm{Fe}$ in wheat bran is utilized very well by rats (Morris \& Ellis, 1976), and that the remaining $\mathrm{Fe}$ is mainly $\mathrm{FeSO}_{4}$, a well-absorbed source of Fe. Since there may be a difference between rats and humans with respect to the inhibitory effect of wheat bran on $\mathrm{Fe}$ availability, extrapolation of the results of the present study to the human situation should be viewed cautiously. Nevertheless, the clear demonstration that Beta Fibre significantly increased $\mathrm{Fe}$ absorption is an extremely interesting and important finding that warrants further investigation into the factors responsible for this effect.

Absorption of $\mathrm{Zn}$ from the meal containing wheat bran was less than that from $\mathrm{ZnCO}_{3}$. Yet the addition of Beta Fibre to the semi-synthetic diet significantly increased $\mathrm{Zn}$ absorption. Unlike Fe, the validity of using extrinsic labels in $\mathrm{Zn}$ bioavailability studies is uncertain. The two test materials had very different $\mathrm{Zn}$ concentrations, necessitating two $\mathrm{ZnCO}_{3}$ control groups. In the case of the wheat-bran test meal, $72 \%$ of the total $\mathrm{Zn}$ came from wheat bran, whereas in the Beta Fibre test meal only $20 \%$ came from Beta Fibre. If the added ${ }^{65} \mathrm{Zn}$ label did not fully exchange with the $\mathrm{Zn}$ in the meal, the different proportions of $\mathrm{Zn}$ from test material, diet and $\mathrm{ZnCO}_{3}$ could have contributed towards the higher absorption of ${ }^{65} \mathrm{Zn}$ from the Beta Fibre than from the wheat-bran test meal. The difference in dose is also an important consideration since percentage absorption of $\mathrm{Zn}$, like $\mathrm{Fe}$, falls with increasing dose. Indeed, there was a much higher percentage absorption from the control group given the semi-synthetic diet with the lower amount of added $\mathrm{ZnCO}_{3}$. Regarding $\mathrm{Fe}-\mathrm{Zn}$ interactions, the level of $\mathrm{Fe}$ would not have been high enough to cause inhibition of $\mathrm{Zn}$ absorption in any of the test meals (Fairweather-Tait \& Southon, 1989).

One other study in the literature (Sandström et al. 1987) has specifically examined the effects of sugar-beet fibre on $\mathrm{Zn}$ absorption from (a) a breakfast-type meal in which the sugar-beet fibre was added as muesli or incorporated into bread, and (b) a meat meal in which the sugar-beet fibre was used as a meat extender. Unfortunately the design of the experiment did not permit any conclusions to be drawn about the effects of sugar-beet fibre on $\mathrm{Zn}$ bioavailability. However, the results demonstrated that partial replacement of meat, generally recognized as being a well-absorbed source of $\mathrm{Zn}$, with sugar-beet fibre did not reduce $\mathrm{Zn}$ bioavailability. 
The results presented in the present paper demonstrated that sugar-beet fibre, unlike wheat bran, had no adverse effects on Fe or $\mathrm{Zn}$ absorption. When added to a semi-synthetic diet at levels comparable with human diets it significantly increased both $\mathrm{Fe}$ and $\mathrm{Zn}$ bioavailability. Thus sugar-beet fibre would appear to provide a valuable source of complex carbohydrates without the undesirable mineral-binding characteristics common to many 'high-fibre' foods. It would be particularly useful for groups of the population potentially at risk with respect to mineral nutrition, including infants and growing children, pregnant and lactating women, the elderly, and people on long-term weight-reducing regimes. Further work is required to elucidate the mechanisms involved in the enhancement of $\mathrm{Fe}$ and $\mathrm{Zn}$ absorption, and to determine whether the effects seen in rats also apply to man.

The authors thank Dr Janice Harland and British Sugar for financial support, $\mathrm{Mr}$ R. Faulks for fibre analysis, and Mrs J. Cooke for assistance with the animals.

\section{REFERENCES}

Bailey, N. T. J. (1964). Statistical Methods in Biology, pp. 47-49. London: Hodder and Stoughton.

Bjorn-Rasmussen, E., Hallberg, L. \& Walker, R. B. (1973). Food iron absorption in man. Il. Isotopic exchange of iron between labeled foods and between a food and an iron salt. American Journal of Clinical Nutrition 26, 1311-1319.

Cook, J. D., Noble, N. L., Morck, T. A., Lynch, A. R. \& Petersburg, S. J. (1983). Effect of fiber on nonheme iron absorption. Gastroenterology 85, 1354-1358.

Englyst, H., Wiggins, H. S. \& Cummings, J. H. (1982). Determination of the non-starch polysaccharides in plant foods by gas-liquid chromatography of constituent sugar as alditol acetates. Analyst 107, 307-318.

Fairweather-Tait, S. J. \& Southon, S. (1989). Studies of iron:zinc interactions in adult rats and the effect of iron fortification of two commercial infant weaning products on iron and zinc status of weanling rats. Journal of Nutrition 119, 599-606.

Fairweather-Tait, S. J. \& Wright, A. J. A. (1984). The influence of previous iron intake on the estimation of bioavailability of Fe from a test meal given to rats. British Journal of Nutrition $\mathbf{5 1}, 185-191$.

Fairweather-Tait, S. J. \& Wright, A. J. A. (1985). Iron availability from peas (Pisum sativum) and bread containing added pea testa in rats. British Journal of Nutrition 53,193-197.

Harland, B.F. \& Oberleas, D. (1986). Anion-exchange method for determination of phytate in foods: collaborative study. Journal of the Association of Official Analytical Chemists 69, 667-670.

Morris, E. R. \& Ellis, R. (1976). Isolation of monoferric phytate from wheat bran and its biological value as an iron source to the rat. Journal of Nutrition 106, 753-760.

Sandström, B., Davidsson, L., Kivistö, B., Hasselblad, C. \& Cederblad A. (1987). The effect of vegetables and beet fibre on the absorption of zinc in humans from composite meals. British Journal of Nutrition 58, $49-57$. 